\title{
LOCUS UNIVERSITAS: \\ (LA CIUDAD COMO ESPACIO QUE EDIFICA LA CULTURA)
}

Antonio Fernández-Alba

$\mathbf{E}$ L descrédito se ha abatido sobre la arquitectura de la ciudad (podríamos señalar recogiendo el juicio de Platón sobre la filosofía en la República, VII) «porque no se la cultiva dignamente; pues no deben cultivarla los bastardos sino los bien nacidos».

El diagnóstico, ciertamente pesimista, que albergan las imágenes descarnadas de la mayor parte de nuestras ciudades, sólo puede justificarse desde las incongruencias e incompatibilidades que enfrentan a los sistemas de producción de los espacios urbanos y los procesos que desarrollan los crecimientos en la civilización que nos encontramos, o si se prefiere entre los presupuestos que marca el desarrollo de la ciudad como «servicio social» en su sentido más creador y amplio del término y el estatu-quo político-económico sobre la ciudad. Sabido es que el capital que nace en la ciudad producto de la nueva cultura urbana emergente es asimilado en un modelo de integración acumulativa, de manera que a medida que se posee mayor concentración de «tejido urbano», son mayores las posibilidades de control sobre el desarrollo de la ciudad. Este modelo en ocasiones se fragmenta en constelaciones suburbanas aparentemente autosuficientes, a veces en hipertrofiadas cornubaciones que hacen sucumbir cualquier rastro de ciudad.

Asistimos por tanto a la búsqueda y posesión de la tierra urbana, a la conquista de sus vacíos y la explotación sin límites de su patrimonio edificado. Frente a este modelo de integración acumulativa, podemos observar por lo que se refiere a la recuperación de la ciudad, una ideología urbana maltrecha por tantos avatares acaecidos durante el desarrollo de la revolución industrial, consolidada después por una teoría de la ciudad legitimada sobre el lucro como principio formalizador de su realidad ambiental. Teoría y práctica en la que aún siguen asentados los «modelos planificatorios», se confiesen o no, y como bien elocuente manifiesta la arquitectura de sus escenografías urbanizadas. Monopolizado el suelo por un proceso de ocupación básicamente mercantil, la ciencia de la ciudad, el urbanismo, y su configuración espacial, la arquitectura, utiliza el territorio de la ciudad, sus centros históricos, los pequeños o medianos asentamientos rurales como 
plataformas para una especulación intrínsecamente económica, al margen de sus valores históricos, o de su patrimonio perceptivo.

De ahí que resulte evidente que la amalgama edificada nada tenga que ver con los lugares anhelados por los nuevos colectivos ciudadanos y menos aún con las posibilidades de los desarrollos de las nuevas tecnologías aplicadas. Para encubrir tan irracionales desmanes, se acude a fórmulas incongruentes como pretender colapsar el crecimiento metropolitano que tiene sus propias leyes de evolución, o bien a recursos de cosmética historiográfica, tratando de recubrir con teatrales arquitecturas y divagatorias contextualizaciones una idílica «pastoral urbana», que tantos adeptos despierta entre los diseñadores epigónicos y la conciencia feliz de sus promotores, lograndos descubrir que el plus-valor semántico puede cotizarse como un lucrativo plus-valor de cambio económico.

Reconstruir la ciudad hoy, racionalizar los desequilibrios ambientales, recuperar los grandes contenedores urbanos abandonados, transferirlos a otros usos, incorporar los soportes de las nuevas funciones de la cultura telemática, acometer la coexistencia entre lo arcaico y lo inmaterial..., son cuestiones que deben orientarse hacia propuestas y proyectos de aproximaciones sucesivas y modificaciones primarias, modificaciones en los dominios de la propiedad del suelo, de la forma de habitar sus espacios, de la relación de sus funciones y sobre todo de estrategias imaginativas en analogía con las conquistas logradas por la evidencia científica y la expresividad artística de nuestro tiempo.

¿Qué de extraño puede tener que unas instituciones como las universidades, por su propia naturaleza dedicadas a integrar saberes dispersos, orienten desde sus propias estructuras teórico-prácticas, en la actualidad en gran parte entumecidas, sus esfuerzos hacia actuaciones conceptuales y prácticas de recuperación, no sólo de la ciudad denominada histórica, sino a integrarse en el proyecto nuevo de ciudad imponiendo su propia ética y la lógica de los conocimientos de sus disciplinas?

La universidad de masas, vinculada a las sociedades posindustriales, se formaliza como institución que tiende a la descentralización. La idea basada sobre el principio de la autosuficiencia del campus, evoluciona hacia un concepto descentralizado, permeable en los distintos resquicios que pueden ser ocupados en la ciudad y donde los servicios colectivos de su organización son compartidos con la comunidad donde reside. Flexibilidad, intercambio, capacidad de crecimiento y descentralización, son algunas de las características más significativas de los modelos universitarios para estas concentraciones masivas en las que se desarrolla la planificación universitaria actual. La ciudad como la universidad se comporta como un sistema de información y comunicación, como lo es la cultura moderna.

De las tensiones manifiestas ya desde los períodos heroicos de las vanguardias: demanda social para legitimar un espacio habitable y control del mercado del suelo, pueden, y de hecho están surgiendo acciones integradas en los propios márgenes de legislación urbanística, que en ocasio- 
nes deben ser utilizados por instituciones como la universidad, dispuestas a superponer al lucro, la racionalidad del proyecto de lo urbano y proporcionar un modelo que pueda operar sobre la ciudad, desde actuaciones elementales de remodelación hasta decisiones de proyectos imaginativos para la evolución de la metrópoli. La historia del pensamiento com la del arte es la historia que construye la ciudad. ¿Cómo entonces, la Universidad puede replegarse en los contenidos de la endogancia de sus claustros o a la obsolescencia de sus doctrinas?

Los saberes universitarios no deben ser tan colaterales a la poética innovadora necesaria para construir los lugares de la ciudad posmaterialista. La componente utópica que se reclama a la arquitectura y el urbanismo después de la derrota de lo moderno, sigue siendo el proyecto de una arquitectura para la ciudad como espacio donde habita la existencia humana como existencia social. ¿Cómo dejar en manos de los diseñadores del estereotipo, de arquitectos del kitsch industrial, de planificadores de la patología urbana el proyecto de un lugar bello para habitar la ciudad?

La región de lo «sublime» en los siglos XVII y XVIII representaba aquella región incierta, frontera de nieblas entre el mundo habitado y lo inhóspito, entre la ciudad y la naturaleza inhabitable, entre la arquitectura de las razones geométricas y los desconocidos mundos del ser. La ciudad se concebía como una fortaleza tangente con lo «sublime», con lo desconocido y transcendente, pero autosuficiente para los significados de la existencia humana.

Nuestro tiempo nos ha desvelado la topografía y los accidentes de esa región incierta y con tal relevación los nuevos límites por los que puede discurrir el acontecer de la otra ciudad, por el momento desconocida, ciudad que no viene acotada ni por la geometría precisa de «la ilustración», pero tampoco por el apocalíptico crecimiento sin control. La ciudad hoy se entiende más como un sistema de servicios prácticamente ilimitados, reproduciendo de nuevo en estos tiempos de la tecno-ciencia aquella investidura ideológica de las vanguardias, según la cual la ideología técnica se traducía en la construcción imaginaria de un espacio ideológico, espacios dotados de una funcionalidad capaz de transformar los hábitos y conductas de la sociedad, al mismo tiempo que eximían a esa sociedad del deber de transformarse.

La segunda naturaleza, naturaleza de raíz técnica en la que se construye la ciudad, ya no se encuentra en los territorios de lo «sublime». Lo desconocido se ha transformado y ha sido recogido en una cartografía precisa donde se nos muestra una selva de artefactos publicitados que pueblan de imágenes nuestro universo cotidiano. Lo transcendente se ha transfigurado en contingencia de consumo tecnologizado y habita en el templo del hipermercado.

La arquitectura y la ciencia urbana han sido relegadas hoy a un papel servil del mercantilismo que domina al poder tecno-científico, y se presentan como disciplinas alejadas de un compromiso cultural, sus proyectos se reducen cada vez más a compromisos con las técnicas de explotación comercial, bajo los subterfugios de la historicidad o la funcionalidad. 
Detrás de la inoperancia de los efectos que ha conseguido la planificación durante el siglo Xx, donde las grandes y nuevas funciones urbanas (flujos de circulación, macroespacios comerciales o industriales) no se tienen en consideración como proyecto global, ante la incongruencia de los espacios de sus arquitecturas preocupados más por la mirada retórica de sus formas que por la construcción de los lugares públicos, se nos presenta la crisis de la ciudad y la metrópoli contemporánea, como postulado de una incapacidad para formular el proyecto de la ciudad-metrópoli irremediablemente artificial, heterogénea y ficticia, fragmentaria y desafectiva para sus habitantes. La naturaleza de sus desarrollos en cada ciclo se vuelve obsoleta, de manera que desde principios de siglo hemos podido contemplar la transfiguración de los diversos sedimentos que constituyen su rápida arqueología urbana.

\section{¿Quién construye la ciudad? ¿Qué proyecto organiza el desarrollo de lo urbano?}

Las sociedades capitalistas avanzadas evolucionan hacia un modelo de producción específica, modelos de producción de estado, sistemas de poder que resultan de un compromiso entre las estructuras de iniciativa privada y la de los postulados del nuevo capitalismo de estado, en los diferentes procesos de gestión y desarrollo, este modelo es en el que orienta la presente ideología del mundo occidental.

La sociedad organizada según los principios de la «economía del deseo», el nuevo capitalismo industrial integrado (C.I.I.): Este modelo viene configurado por las transformaciones y adaptaciones del capitalismo monopolista y las alternativas que propone el capitalismo de estado. Estas relaciones integran no sólo clases castas sociales, políticas y económicas, sino los espacios y los contenidos en los que se desarrolla la ciudad.

El proyecto que este modelo (C.I.I.) por lo que se refiere a la construcción de la arquitectura de la ciudad se ve circunscrito, bien a un «formalismo técnico» que dé respuesta a las infraestructuras de la movilidad y los grandes macroespacios para el consumo (movilidad+consumo, como se sabe son los factores de mayor incidencia en la construcción de la metrópoli moderna), o bien en un «formalismo historicista», que pretende mantener mediante costosas cosméticas las viejas tramas urbanas de la ciudad construida.

La cultura que desarrolla este modelo C.I.I. en la ciudad marca una división sin paliativos entre la experiencia subjetiva y toda la cosmogonia de artefactos que constituyen el hipermercado de necesidades ficticias, una fractura entre la persona y los escenarios metropolitanos que conduce a la negación del individuo en el territorio de lo urbano.

La negación del individuo, pese a tanta literatura humanizadora de las vanguardias teóricas es una tendencia implícita en el proyecto de la arquitectura moderna. Esta abolición de la identidad se plantea ya en la ciudad del protorracionalismo en una doble valoración, como concepto y como uso de la ciudad como individuo y como grupo, como estilo individual y estilo colectivo, en la conducta que debe aceptar paradójicamente el proyecto del arquitecto, cobra un protagonismo 
fuera de lugar, su expresión individual interpreta y reproduce la pluralidad estilística de las formas, los espacios y la conducta que ha de habitar en la máquina de la ciudad.

La negación de la identidad en la ciudad, la fractura entre persona y medio urbano, produce la necesidad de prolongar la historia individual, llena de silencios, en un diálogo con los artefactos técnicos de comunicación, con los medios informatizados que pueblan los ámbitos de la democracia espectacular. En la calle sólo quedan los expedientes nemotécnicos del caminante solitario según la melancólica cita de W. Benjamin, el dentro y el fuera, interior y exterior sólo se perciben por los códigos que señalan las demandas del consumo. Signos que vienen a ser como desiertos distantes de su individualidad arrebatada, tangentes sólo por la contingencia del consumo, esa necesidad fingida, propiedad aplazada, donde también el objeto se ha quedado sin lugar. Su propiedad sólo se adquiere por el otear posesivo, por la percepción transitoria, como mirada mediadora de la identidad perdida. La mirada entretenida en la calle de los objetos alineados, de la mercancía afamada de los signos, rasgos publicitarios, autógrafos anónimos, marcas registradas, astrolabio del dinero, efímeras consignas, sintagmas benéficos, códigos cromados, arquitectura en fin, de las mil filigranas. La metrópoli como guía de la separación entre hombre y medio de este epistolario codificado del adiós, desahucio del yo en el habitar de la gran metrópoli.

Nuestros cuerpos en la infancia rozaron aún los muros de la ciudad que albergaba la atmósfera de los ensueños de la niñez, nuestra adolescencia y madurez ya enmudece en la patria de los «inmateriales de la metrópoli», errantes vagamos en el azar de la jungla telemática. El hombre disociado dejó el corazón en la ciudad herida y trata ahora en lo que es ciudad confusa, de asimilar con razonada esquizofrenia las promesas que bordean sus luminosos mensajes.

Infancia metropolitana a la que ahora asistimos. La ciudad quedó vencida irremediablemente con sus recuerdos, símbolos y fetiches. La ciudad como memoria abolida de las cosas, de ella nos queda sólo la mirada de los objetos transitorios, pero los objetos como las cosas, desalojadas del recuerdo son efímeras. El cuerpo del hombre hace tiempo que fue arrojado del edén urbano y hoy su alma ya divaga por las «geometrías de la angustia», entre colinas de rojas arcillas y menhires de transparente celofán.

El diagnóstico pese a su complejidad, no parece ni distante ni confuso. La ciudad, ya invadida por la ideología metropolitana, requiere de una teoría y un proyecto desde la imaginación del saber, una teoría integrada por el conocimiento epistemológico sobre la metrópoli, y un proyecto multidisciplinar efectivo que arranque los estereotipados esquemas del lineal discurso arquitectónico-urbanístico sobre la ciudad. Un pensamiento que haga efectivo el entender al espacio metropolitano como un proyecto positivo y creador, operativo y transformador, y sobremanera productivo, que supere los monumentos melancólicos de los teólogos-arquitectos y el desolado paisaje que construyen los astrónomos-urbanistas. 
¿Qué hacer? Una actitud beligerante por parte de los saberes más positivos y creadores de la universidad de hoy, deberían incorporarse sin dilación al proyecto de la construcción de los «lugares universales» de la ciudad, al «universo de lugares»: imágenes, sensaciones, impulsos mentales, canales de comunicación que constituyen las «regiones sublimes» del confuso y fragmentario universo de nuestras metrópolis. «El camino, puede y debe ser exclusivamente la escuela, en todos sus niveles, en todas sus ramas y la escuela, cualquier escuela, debe educar para construir la ciudad como forma sensible de la civilización», G. Carlo Argan (Historia del Arte como Historia de la ciudad, página 203).

La ciudad entendida, como un «locus universitas», proyectado no por el «descrédito de los bastardos, sino por la inteligencia de los bien nacidos». La ciudad concebida como espacio edificado por la cultura.

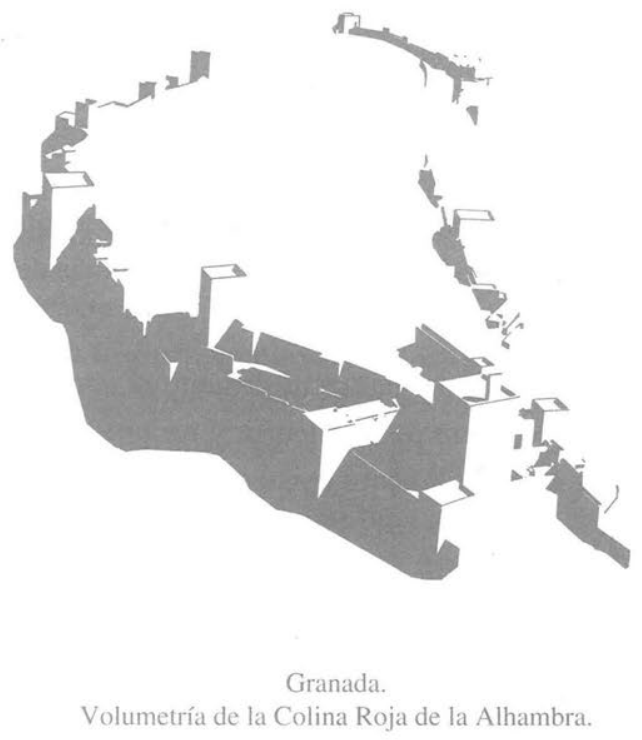

